\title{
A IMPORTÂNCIA DE SER BRASILEIRO
}

\section{Boaventura de Sousa Santos*}

Espero que os meus patrícios não se ofendam se eu confessar que, neste período eleitoral, gostaria de ser brasileiro. Para poder votar. Contudo as razões do meu interesse em votar decorrem do fato de eu não ser brasileiro e avaliar o significado dos resultados das próximas eleições não apenas pelo seu impacto no país, mas sobretudo pelo seu impacto no mundo. A importância de ser brasileiro decorre precisamente do fato de o que acontece hoje no Brasil ser importante para o resto do mundo. À luz desse futuro, são dois os meus desejos e os meus votos: ser brasileiro para votar em Lula, ser gaúcho para votar em Tarso Genro.

As minhas razões para votar em Lula são duas. A vitória de Lula representa a verdadeira e exitosa conclusão da transição democrática iniciada em meados da década de 80. A quem, como eu, acompanhou de perto o Brasil nos últimos 20 anos não escapam as profundas mudanças políticas que ocomeram não apenas no nível das instituições, como, sobretudo, no das práticas e das sociabilidades dos brasileiros no seu dia-a-dia.

O código social do "sabe com quem está falando" foi pouco a pouco sendo confrontado com a consciência e a linguagem dos direitos e da cidadania, com a emergente capacidade coletiva dos movimentos e das organizações populares de formular demandas e exigir o comprometimento ético dos govemantes. Em suma, ainda que de uma maneira seletiva e regionalmente desigual, está a emergir no Brasil uma nova esfera pública, uma nova cultura política. Sendo o Brasil um dos países mais injustos do mundo, essa emergência democrática está sempre à beira da frustração e da vulnerabilidade à ocorrência de novos autoritarismos. Para que tal não aconteça, tem de ser consolidada através de práticas políticas éticas, transparentes, participativas e redistributivas. Nenhum partido tem tantas credenciais nesse domínio como o PT. A segunda razão para votar em Lula diz respeito ao momento da globalização neoliberal. Não são os críticos esquerdistas que põem hoje em causa o sistema financeiro intemacional, são as vozes particularmente autorizadas dos que o conhecem por dentro e têm acesso a informação que mais ninguém tem. A irracionalidade e a injustiça do sistema são hoje do domínio público e o consenso que se está a gerar a seu respeito não pode deixar de levar a transformações em curto prazo. Quem está em melhores condições para govemar os países nos tempos que se avizinham? Não, certamente, quem se formou na obediência cega

* Boaventura de Sousa Santos, 61, sociólogo, é professor catedrático da Faculdade de Economia da Universidade de Coimbra (Portugal). 
à ortodoxia, porque esse vai comer o risco de ser recorrentemente mais papista que o papa e não vai ser capaz de explorar as novas capacidades de manobra que se vão abrir. FHC govemou o país num período de fundamentalismo neoliberal e de algum modo contribuiu para ele. No entanto, o futuro creditar-lhe-á o fato de, apesar disso, não ter bloqueado a efervescência democrática de que falei acima. $\mathrm{O}$ modelo que seguiu está hoje num beco sem saída e é precisamente dessa efervescência democrática que advirão as energias políticas para uma apropriação pacífica e justa das novas condições. Daí que, embora com isso possa chocar muitos dos meus amigos (incluindo o FHC), penso genuinamente que Lula é o melhor sucessor de FHC, único capaz de ultrapassar o impasse a que a ortodoxia chegou, resgatando o que ela não foi capaz de destruir. No plano intemacional, a vitória de Lula significa a credibilidade de uma transição pacífica e gradual por parte de um grande país para um novo pacto financeiro e econômico global, mais equilibrado e mais comprometido com o bem-estar dos cidadãos.

\section{Ainda que de uma maneira seletiryionalmente desigual, está a engir no Brasil uma nova cultura política}

O meu segundo desejo é o de ser brasileiro e gaúcho, para poder votar em Tarso Genro. Eis as razões. A primeira diz respeito ao modo ímpar como Tarso Genro soube transformar a sua reflexão política num sistema e numa prática político-administrativos capazes de combinar igualdade e eqüidade, solidaniedade e democracia, participação e eficiência. Refiro-me, obviamente, ao Orçamento Participativo, inovação institucional que tem ainda hoje em Porto Alegre a sua melhor expressão. Trata-se de uma inovação que pertence por inteiro ao PT gaúcho, mas a que Tarso Genro soube dar uma expressão particularmente consistente. Tarso Genro é considerado internacionalmente um dos teónicos mais brilhantes da democracia de alta intensidade, mas, diferentemente de outros teóricos, tem uma obra que fala eloquentemente por ele. A segunda razão tem a ver com o fato de Porto Alegre e 0 Rio Grande do Sul serem hoje o símbolo da viabilidade de uma globalização alternativa, que combine os objetivos do desenvolvimento e da eficiência com os objetivos da eqüidade e da democracia. Porto Alegre é a cidade global das altemativas e o prestígio intemacional que daí lhe advém traduz-se em vantagens sociais e econômicas que podem ser colhidas até por aqueles que, confinados a vistas curtas, rejeitam a idéia de que possa haver outra globalização para além da neoliberal. Essa preeminência intemacional, que tem hoje uma concretização dramática no Fórum Social Mundial, assenta-se na idéia de que a democracia, a tolerância e a solidariedade, levadas a sério, contêm em si as sementes de um outro mundo possível, mais justo e mais sustentável. É por isso que a vitónia de Tarso Genro, sendo uma vitória gaúcha, é também uma vitónia do mundo democrático. 